\title{
SELF-ESTEEM AND LONELINESS AS FACTORS AFFECTING DISTANCE LEARNING STUDENTS
}

\author{
MariaVakoufari [mavakoufari@yahoo.gr],AngelakiChristina[cangelaki@yahoo.com], \\ Ilias Mavroidis [imavn@tee.gr], Hellinic Open University, Patras, Greece
}

\begin{abstract}
This study aims at empirically examining the relation of self-esteem and loneliness with social presence, academic performance, satisfaction with the course and intention for academic drop out, in a blended distance learning environment in Greece. The study involved both undergraduate and postgraduate students of the Hellenic Open University (HOU). Data were collected via a four-section questionnaire. The correlational data analysis yielded a negative correlation between self-esteem and intention for academic drop out, while there is a positive correlation between self-esteem and satisfaction derived from the course. Results also suggested that there is no correlation between self-esteem and academic performance. Findings also revealed that there is no statistically significant correlation between loneliness and the other variables under examination. Furthermore, the results showed that there were no statistically significant differences between the examined variables in relation to the demographic features (gender, age, etc.). The findings of the present study are discussed in relation to the relevant literature, taking into consideration the blended learning educational format offered by the HOU which is based on methodologies used in other European institutions that offer distance learning courses. Finally, recommendations for further research are presented.
\end{abstract}

\section{Introduction}

Distance learning is a constantly evolving method of education with specific features, on the grounds that distance learning students study away from both the tutor and the educational organization (Keegan, 1986; Holmberg, 1995). Distance learning presents an alternative educational intervention, which can be applied globally reducing the limitations and the difficulties of access posed by conventional systems. At the same time, the field of distance learning is rapidly evolving in order to satisfy the constantly increasing demand for life-long education. Consequently, distance learning is a major field offering education whose several aspects are different compared to those of conventional methods of education. The specific characteristics of distance learning, emanating from the distance between the students and the tutor as well as the institution have created a great research interest in relation to the factors determining the successful participation of learners in a distance learning environment.

In this respect, great significance is attributed to the relation of factors such as self-esteem and loneliness with academic performance, academic drop out and satisfaction with the course in a distance learning environment (Workman \& Stenard, 1996; von Prummer, 1990; Kurtz, AmichaiHamburger \& Kantor, 2009). In addition, social presence is a fundamental element of distance learning since it is closely related to the learning process. Social presence has been found to enhance students' performance as well as their satisfaction with the course (Garrison et al., 2000; 
Richardson \& Swan, 2003; Gunawardena \& McIsaac, 2004; Garrison \& Arbaugh, 2007; So \& Brush, 2008).

Taking into consideration the significance of self-esteem and loneliness in conventional education (Byrne, 1984; Bryan, 1997; Lane, Lane \& Kyprianou, 2004) as well as the fact that these factors have an even more important role to play for distance education students, this study seeks to examine the correlation of these two factors with academic features such as academic performance, academic drop out, satisfaction with the course as well as with social presence. Social presence is examined as it is a major factor differentiating distance education from conventional methods of education. Such a study is rather significant in the context of HOU as it is a relatively new public educational organization and the unique university which offers exclusively distance learning courses in Greece. The research issues examined until now in relation to the HOU, are mainly linked to the tutor's multifaceted role, the quality as well as the effectiveness of the offered distance learning courses, the tutor-student and student-student communication (Giossos, Mavroidis \& Koutsouba, 2008).

\section{Theoretical Framework}

\section{Self-esteem}

According to Rosenberg and Simmons (1975) self-esteem is an individual's overall attitude, either positive or negative towards himself or herself. Harmon-Jones et al. (1997) define self-esteem as somebody's beliefs concerning how well they live up to the value standards set by the society which they live, while according to Branden, (2001) self-esteem refers to a perspective compromising an individual's value while postulating his or her self-evaluation and selfdescription in a variety of fields. Moreover, Baumeister et al. (2003) considered successful performance in a learning task as an essential component to achieve a considerable rise in one's self-esteem. Byrne (1984) and Marsch (1990) concluded that self-esteem is tightly linked with academic performance while the results of the research of Lane et al. (2004) on the relationship between self-esteem, self-effectiveness and academic performance revealed significant correlations between self-esteem and academic performance. In addition, self-esteem was considered by Peixoto and Almeida (2010) as a strong outcome predictor regarding the academic performance. Moreover, self-esteem was devised as a significant factor as it is tightly linked to psychological well-being (Neff, 2011). Self- esteem is also related to academic drop out (Finn, 1989; Weinner, 2000). Griffiths, Sharkey and Furlong (2009) have considered self-esteem as a fundamental factor which might affect student engagement. Self-esteem has been associated with the satisfaction that learners get from the course, too. Individuals with high levels of self-esteem have been considered to be more satisfied with the course that they attended as well as with their personal life in general (Bhagat \& Chassie, 1978; Skaalvik, 1983; Hirsch \& DuBois, 1991).

\section{Loneliness}

According to Weiss (1973), there are two types of loneliness; a) social loneliness, that is defined as the lack of social relationships connecting an individual with the society to which he or she belongs, and b) emotional loneliness, defined as lack of specific interpersonal relationships. Furthermore social solitude is a tool for measuring human social interaction which represents the presence or absence of interpersonal relationships, the latter called loneliness. The need of belonging is listed high in the rank in Maslow's (1971) Hierarcby of Needs. Tajfel and Turner (1986) claimed that being a part of a group within which somebody shares their interests and goals will probably boost their self-esteem, a fact that is considered to be significant for one's well-being according to Branden (1969). Loneliness has been examined in the framework of education and learning. School performance is inversely related to the feeling of loneliness and social 
dissatisfaction at school (Valas, 1999). Loneliness was also found to be associated with social interactions and self-esteem according to Cheng and Furnham (2002).

\section{Self-esteem and loneliness in distance learning}

The previous sections provided a discussion of self-esteem and loneliness in relation to education in general. Distance learning is a field of education with specific features, which differentiate it from conventional methods of learning. Self-esteem and loneliness motivate similar hypotheses related to the field of distance education, which should be examined.

Workman and Stenard (1996) underlined the important role of self-esteem in distance learning. They claimed that rising students' levels of self-esteem is very important in distance learning courses and they related this rise with reduction of the possibility of academic drop out. Moreover, according to von Prummer (1990) learners, mainly female ones which aim at rising their self-esteem, choose to enrol in a distance learning course while Kurtz et al. (2009) reported that there is a positive correlation between self-esteem and students' attitude toward online learning. It should be noted that Pullmann and Allik (2008) suggested that low self-esteem is not necessarily a sign of poor academic performance.

Dillon, Gunawardena and Parker (1992) reported that interpersonal communication is considered as a very important factor by students as it reduces the feeling of loneliness. Angelaki and Mavroidis (2013) concluded that both tutor-student and student-student communication play an important role in alleviating the intensity of negative emotions such as loneliness and solitude experienced by HOU students. Moreover, according to Tinto (1993) loneliness in distance learning is related to academic drop out. He reported that when students experience loneliness and they do not feel part of the learning community, it is highly likely that they will drop out. $\mathrm{He}$ also concluded that the sense of belonging to a group makes them feel engaged toward the distance learning provider. However, the study of Kurtz et al. (2009) suggested that there is no correlation between loneliness and students' attitude towards e-learning.

\section{Social Presence}

Social presence has been considered as a fundamental element of distance learning and has been defined by Short et al. (1976, p.65) as "the degree of salience of the other person in the interaction and the consequent salience of the interpersonal relationships". In other words this can be interpreted as the extent to which a person is perceived as "real" in mediated communication (Richardson \& Swan, 2003). More recently, Garrison et al. (2000, p.89) defined social presence as "the ability of participants in a community of inquiry to project their personal characteristics into the community thereby presenting themselves as real people". Regarding the latter definition, Rourke and Kanuka (2009) underlined that operationally, it is devised as the frequency counts of emotional, cohesive and open communicative action in computer mediated communication. Bayne et al. (2014, p.581) examined the social topologies of distance students and suggested that "the material campus continues to be a symbolically and materially significant 'mooring' for a group of students who may never physically attend that campus". Tu (2002) has focused on the psychological connections between learners, while Hratsinski (2009), So and Brush (2008) and Richardson and Swan, (2003) highlighted the important effect of social presence on the learning process as it enhances students' performance as well as satisfaction with the course and the instructor. Activities boosting perception of social presence have also been found to be positively related to learning and students' satisfaction with the course (Garrison et al. 2000; Whiteman, 2002; Shin, 2003; Garrison \& Arbaugh, 2007). Gunawardena and Zittle (1997), having examined social presence as a predictor of students' satisfaction in teleconference learning environments, concluded that social presence is a critical predictor of students' satisfaction in online learning environments. Gunawardena et al. (2001) reported that social European Journal of Open, Distance and e-Learning - Vol. 17 / No. 2 
presence facilitates the development of confidence and self-revelation in an online learning environment, while Garrison (2011) considers it as a substantial construct in a collaborative constructive approach of learning. Finally, in relation to the interconnection of technological and social parameters in distance learning, Bayne (2014) notes that "casting the technological and the social as isolated from each other in the context of digital (and post-digital) education merely robs the field of its complexity and richness".

\section{Methods}

\section{Context of the HOU}

The HOU is the only public educational organisation in Greece offering exclusively distance learning courses since 1998. HOU based its distance learning methodology on those used in other European institutes offering distance learning courses, such as the Open University of United Kingdom (Lionarakis, 2005). HOU consists of four Schools: 1) School of Humanities 2) School of Social Sciences 3) School of Science and Technology and 4) School of Applied Arts. It offers 27 postgraduate and 6 undergraduate courses. All the courses are addressed to adults. Postgraduate students are awarded a Master's degree upon successful completion of four course modules and a dissertation while undergraduate students are awarded a degree after having successfully completed twelve course modules. HOU also offers $\mathrm{PhD}$ degrees. Possession of a High School Certificate is required for undergraduate students, while applicants to postgraduate courses have to possess an undergraduate degree in a relevant field.

During the ten-month academic year students must hand in 3-6 written assignments. The total number of the written assignments required depends on the course. At the end of the academic year students sit exams so that the course module can be successfully completed. In addition, each course module includes five Counseling Group Session (CGS). The students are not obliged to participate in these face-to-face meetings. Students are in charge of planning their own study during the course while they are continuously supported by the academic staff. The tutor to student ratio is approximately one to thirty. The HOU mainly uses hardcopy educational material as well as multimedia material such as CDs, DVDs and CD-ROMs. Only very recently it has started using more online tools, such as a web-based instructional environment / portal, where there is a dedicated website for each module course. The portal simplifies organisational procedures. It also aims at enriching students' learning opportunities as it provides forums for asynchronous tutor-student as well as student-student interaction. The use of most of the features of the portal, which started operating a couple of years ago, is optional and so far the use of the forums by the students and tutors has been minimal, especially in the School of Humanities where the present study has been conducted. Student-tutor interaction and communication are mainly held by e-mail and telephone (Angelaki \& Mavroidis, 2013).

\section{Research questions}

The current study focuses on the following five research questions.

1. What is the relationship between self-esteem and academic performance, self-esteem and academic drop out, self-esteem and satisfaction with the course?

2. What is the relationship between self-esteem and social presence?

3. What is the relationship between loneliness and academic performance, loneliness and academic drop out, loneliness and satisfaction with the course?

4. What is the relationship between loneliness and social presence?

5. Are there any demographic differences (e.g. gender, age etc) in relation to the above parameters? 


\section{Research Design}

A correlation research was designed in order to answer the research questions. The dependent variables included perceived self-esteem, loneliness, perceived social presence, academic performance, intention of academic drop out and satisfaction with the course in general. Correlations were also run between the above variables and demographic variables. One limitation concerning the correlational method is that although this kind of research method can establish a relationship between the correlated variables, it cannot establish a cause-effect relationship.

\section{Sample}

Taking into consideration the purposes of this research study a purposive sample of $80 \mathrm{HOU}$ postgraduate and undergraduate students was selected. Purposive sampling is defined by Neuman (2003) as an acceptable type of sampling for special situations where the researcher intends to identify particular types of cases for in-depth investigation. Though purposive sampling does not give population validity, its logic lies in choosing information rich cases for studying them in depth (Stake, 1995).

More specifically, the sample comprised students of the undergraduate course "Business Administration" and students of the module course "Distance Learning" of the postgraduate course "Studies in Education". The students of both courses were considered to be typical cases of the HOU student community as they were adults with no or little previous experience in distance learning courses. Statistical analysis yielded no significant differences between the students of the two courses in relation to their personal traits and distance learning experience. Based on this analysis the 80 students who took part in the study are treated as a unified group.

The questionnaire was disseminated to the students at the beginning of the $3^{\text {rd }}$ CGS meeting of each course in February 2013. The students were informed about the purposes of the study. The anonymity of the participants was also guaranteed. Participation in the study was voluntary and participants were invited to have access at the results of the study if they wished to do so.

Female participants outnumbered male participants $(60.0 \%$ vs. $40.0 \%)$. Most of them were aged between 31-40 (45.8\%). The majority of the participants $(61.4 \%)$ were postgraduate students, lived in urban areas of $(84.3 \%)$, had no previous experience in distance learning courses $(85.5 \%)$, they were married $(71.1 \%)$ and most of them had children $(65.1 \%)$.

\section{Survey tool}

The survey instrument used for measuring the variables for the current study was based on the approach and research tools used by other researchers examining similar research questions but also on questionnaires especially constructed for the present study. More specifically:

- Self-esteem was measured using the State Self-Esteem Scale (SSES) constructed by Heatherton and Polivy (1991). SSES consists of twenty (20) positive and negative statements concerning one's self-concept ranking from 1 - the lowest (negative) to 5 the highest (positive).

- Student loneliness was measured using the revised UCLA Scale by Russel (1996). The UCLA Scale consists of 19 questions about one's social relations. The respondents rated each question according to the frequency of applicability using a five-point Likert scale ranking from 1 (never) to 5 (always). Half of the questions were negative. Therefore they were coded inversely. 
- Measurement of social presence was based on a social presence scale originally constructed by Gunawardena and Zittle (1997) examining social presence as a predictor of students' satisfaction within computer-mediated conference environments. Gunawardena and Zittle's social presence scale was modified from the original in order to be adapted to the needs of the present study. The modified scale consisted of fourteen (14) statements about social presence in the framework of communication in distance learning. These items, used a five-point Likert scale ranking from 1 (strongly disagree) to 5 (strongly agree) and prompted students to indicate the degree to which they agreed with each statement.

- Academic performance was measured using information derived by the students regarding the final score at each of the course modules they had successfully completed by the time the research was carried out. The final score of this variable was derived from the average of the scores in each course module.

- Regarding academic drop out, students were asked to report if they had ever thought of dropping out by rating the intensity of their thought using a five-point Likert scale ranking from 1 (Not at all) to 5 (Very much). In addition, participants were asked to briefly mention a few reasons leading them to think of dropping out. Therefore, the questionnaire investigates the students' "intention of dropping out"

- Students' satisfaction with the course was measured with a questionnaire based on the scale used in the studies of Arbaugh (2000) and Ali et al. (2011) and adapted for the present study. It consists of eight (8) statements rated by the students according to the degree to which they agree or disagree, using a 5-point Likert scale ranking from 1 (strongly disagree) to 5 (strongly disagree).

\section{Data analysis}

The collected data were analysed using the statistical software SPSS 19. The following statistical indices and coefficients mentioned below were used for the data analysis:

1. Frequency and percentage were used for analyzing the categorical variables while mean score and standard deviation were used for analyzing the ordinal variables.

2. The Pearson correlation coefficient $[\mathrm{r}]$ was used for examining the relation of the variables of (i) loneliness and (ii) self-esteem with the variables of a) academic performance, b) academic drop out, c) satisfaction with the course and d) perceived social presence.

3. The nonparametric Mann-Whitney $U$ test was used for comparing the differences between (i) male and female participants, between (ii) students with or without previous experience in distance learning courses and between (iii) married and single/divorced students, regarding a) academic drop out, b) self esteem, c) satisfaction from the course, d) loneliness and e) perceived social presence.

4. The nonparametric Kruskal Wallis $\mathrm{H}$ test was used for comparing the differences of a) academic drop out, b) self-esteem, c) satisfaction with the course, d) loneliness and e) perceived social presence (i) in relation to the age group the students belonged to, as well as (ii) in relation to the students' academic background.

\section{Validity and Reliability of the survey tool}

The validity tests performed by the developers of the initial questionnaires on which the survey instrument used here is based, can guarantee the validity of the survey tools used for the present study. Concerning the self-esteem scale, Heatherton and Polivy (1991) refer to studies confirming the psychometric aspects of the scale as well as the high levels of construct validity of this scale for measuring self-esteem. Russel's (1996) paper provides strong evidence regarding the validity of the UCLA Loneliness Scale since it has been proved to be strongly correlated with other scales 
measuring loneliness. Finally, Gunawardena and Zittle (1997) also proved the validity of their questionnaire on the perception of social presence.

The reliability of the scales was estimated using the Crobach's alpha [a] coefficient of internal consistency. The internal consistency of the self-esteem scale of this study is $a=.73$ which is considered as a very good level of internal consistency. Additionally the internal consistency (Cronbach's alpha) for the loneliness is $a=.93$, for social presence scale is $a=.92$ and for the scale of satisfaction with the course is $a=.84$, all of them corresponding to very good levels of internal consistency.

\section{Results}

\section{The relationship of self-esteem and loneliness with academic performance, academic drop out, satisfaction with the course and perceived social presence}

Descriptive statistics such as the mean score and the standard deviation were used on the grounds that the measured variables were ordinal.

Table 1: Mean values, standard deviations of the variables under research

\begin{tabular}{|l|c|c|}
\hline Variable & Mean value & SD \\
\hline Self-esteem & 3.85 & .546 \\
\hline Satisfaction with course & 3.79 & .661 \\
\hline Loneliness & 2.27 & .622 \\
\hline Social Presence & 3.32 & .687 \\
\hline Academic drop out & 1.89 & 1.155 \\
\hline
\end{tabular}

An examination of Table 1 shows that the values of self-esteem, satisfaction with the course and social presence are above average while the value of loneliness is low. The value of academic drop out is rather low, but the fact that the standard deviation is higher shows that the values are not so close to the mean score and they are quite dispersed.

Table 2: Pearson correlations of self-esteem and loneliness with academic performance, academic drop out, satisfaction with the course and perceived social presence

\begin{tabular}{|l|c|c|c|c|}
\hline & $\begin{array}{c}\text { Academic } \\
\text { performance }\end{array}$ & $\begin{array}{c}\text { Academic drop } \\
\text { out }\end{array}$ & $\begin{array}{c}\text { Satisfaction with the } \\
\text { course }\end{array}$ & $\begin{array}{c}\text { Perceived Social } \\
\text { presence }\end{array}$ \\
\hline Pearson $r$ & & & & $.257^{*}$ \\
\hline Self-esteem & .031 & $-.234^{*}$ & .042 & .20 \\
\hline Loneliness & .015 & .11 & -.043 \\
\hline
\end{tabular}

${ }^{*} p<.05$

An examination of Table 2 shows that the relation between self-esteem and academic drop out $(\mathrm{r}=-.234, \mathrm{p}<.05)$ is statistically significant. In particular the yielded correlation is negative, that is the two variables are related inversely. In addition, Pearson correlation between self-esteem and satisfaction with the course is also significant. The correlation is positive. In other words students with high self-esteem reported to be more satisfied with the course. Finally, no other significant difference was tracked between the rest of the correlations that were examined.

\section{Gender differences}

The independent variable of gender was examined in relation to the correlations with the dependent variables of self-esteem, loneliness, academic drop out, satisfaction with the course and students' perception of social presence. The Mann-Whitney U test results (Table 3) showed 
that there are no statistically significant differences between gender and the variables mentioned above.

Table 3: Gender differences regarding self-esteem, loneliness, academic drop out, satisfaction with the course and perceived social presence

\begin{tabular}{|l|l|c|c|c|}
\hline \multirow{2}{*}{$\begin{array}{l}\text { I have seriously considered dropping out of my studies at } \\
\text { HOU }\end{array}$} & Gender & $\begin{array}{c}\text { Mean } \\
\text { Rank }\end{array}$ & U & p \\
\hline \multirow{2}{*}{ Self-esteem } & Male & 41.11 & 716.5 & .697 \\
\cline { 2 - 4 } & Female & 39.24 & & \\
\hline \multirow{2}{*}{ Satisfaction with the course } & Male & 43.52 & 671.5 & .343 \\
\cline { 2 - 4 } & Female & 38.49 & & \\
\hline Loneliness & Male & 38.52 & 704.5 & .532 \\
\cline { 2 - 4 } & Female & 41.82 & & \\
\hline Social Presence & Male & 42.74 & 659.0 & .393 \\
\cline { 2 - 4 } & Female & 38.23 & & \\
\hline
\end{tabular}

\section{Influence of previous experience in distance learning}

The independent variable of previous experience in distance learning was examined in relation to the dependent variables of self-esteem, loneliness, academic drop out, satisfaction with the course and students' perception of social presence. The independent variable of previous experience in distance learning was measured dichotomically (yes/no). Therefore the Mann-Whitney U test was used for investigating the correlation of previous experience in distance learning with the independent variables mentioned above. The results of the Mann-Witney $U$ test are shown in Table 4, where the $U$ value, the level of statistical significance (p) and the mean value (Mean Rank) are presented. The yielded correlations are statistically insignificant.

Table 4: Influence of previous experience in distance learning on self-esteem, loneliness, academic drop out, satisfaction with the course and perceived social presence

\begin{tabular}{|c|c|c|c|c|}
\hline & $\begin{array}{c}\text { Previous } \\
\text { experience in } \\
\text { DL } \\
\end{array}$ & $\begin{array}{c}\text { Mean } \\
\text { Rank }\end{array}$ & U & $\mathbf{p}$ \\
\hline \multirow{2}{*}{$\begin{array}{l}\text { I have seriously considered dropping out of my studies } \\
\text { at HOU }\end{array}$} & Yes & 32.60 & \multirow[t]{2}{*}{271.0} & \multirow[t]{2}{*}{.182} \\
\hline & No & 42.18 & & \\
\hline \multirow[t]{2}{*}{ Self-esteem } & Yes & 38.77 & \multirow[t]{2}{*}{360.5} & \multirow[t]{2}{*}{.683} \\
\hline & No & 41.92 & & \\
\hline \multirow[t]{2}{*}{ Satisfaction with the course } & Yes & 39.91 & \multirow[t]{2}{*}{373.0} & \multirow[t]{2}{*}{.811} \\
\hline & No & 41.75 & & \\
\hline \multirow[t]{2}{*}{ Loneliness } & Yes & 51.50 & \multirow[t]{2}{*}{269.5} & \multirow[t]{2}{*}{.111} \\
\hline & No & 39.35 & & \\
\hline \multirow[t]{2}{*}{ Social presence } & Yes & 39.77 & \multirow[t]{2}{*}{371.5} & \multirow[t]{2}{*}{.852} \\
\hline & No & 41.19 & & \\
\hline
\end{tabular}




\section{Age differences}

The independent variable of age was examined in relation to the dependent variables of self-esteem, loneliness, academic drop out, satisfaction with the course and students' perception of social presence. There were four (4) age groups. Therefore the Kruskal-Wallis H test was used for the correlation analysis. The results of the Kruskal-Wallis $\mathrm{H}$ test are shown in Table 5, where the critical value of Chi-squared $\left(\mathrm{X}^{2}\right)$, the level of statistical significance (p) and the mean value (Mean Rank) are presented. The correlations between the variables under examination are statistically insignificant.

Table 5 Age differences regarding self-esteem, loneliness, academic drop out, satisfaction with the course and perceived social presence

\begin{tabular}{|c|c|c|c|c|}
\hline & Age & $\begin{array}{c}\text { Mean } \\
\text { Rank }\end{array}$ & $x^{2}$ & $\mathbf{p}$ \\
\hline \multirow{4}{*}{$\begin{array}{l}\text { I have seriously considered dropping out of my studies at } \\
\text { HOU }\end{array}$} & $<30$ & 43.00 & \multirow{4}{*}{.790} & \multirow{4}{*}{.852} \\
\hline & $31-40$ & 42.69 & & \\
\hline & $41-50$ & 41.42 & & \\
\hline & $>50$ & 35.38 & & \\
\hline \multirow{4}{*}{ Self-esteem } & $<30$ & 21.70 & \multirow{4}{*}{4.126} & \multirow{4}{*}{.248} \\
\hline & $31-40$ & 44.38 & & \\
\hline & $41-50$ & 41.44 & & \\
\hline & $>50$ & 45.63 & & \\
\hline \multirow{4}{*}{ Satisfaction with the course } & $<30$ & 36.50 & \multirow{4}{*}{1.775} & \multirow{4}{*}{.620} \\
\hline & $31-40$ & 43.67 & & \\
\hline & $41-50$ & 38.95 & & \\
\hline & $>50$ & 49.69 & & \\
\hline \multirow{4}{*}{ Loneliness } & $<30$ & 54.60 & \multirow{4}{*}{7.318} & \multirow{4}{*}{.062} \\
\hline & $31-40$ & 35.50 & & \\
\hline & $41-50$ & 42.52 & & \\
\hline & $>50$ & 57.00 & & \\
\hline Social presence & $<30$ & 46.20 & 2.232 & .526 \\
\hline
\end{tabular}

\section{Influence of level of studies}

Students' level of studies was investigated regarding in relation to the dependent variables of self esteem, loneliness, academic drop out, satisfaction with the course and students' perception of social presence. There were five (5) groups concerning the level of studies. Therefore the Kruskal-Wallis $\mathrm{H}$ test was used for the correlation analysis. The results of the Kruskal-Wallis $\mathrm{H}$ test are shown in Table 6 , where the critical value of chi-squared $\left(\mathrm{X}^{2}\right)$, the level of statistical significance (p) and the mean value (Mean Rank) are presented. The analysis did not yield statistically significant correlations between the examined variables. 
Table 6: Influence of level of studies on self-esteem, loneliness, academic drop out, satisfaction with the course and perceived social presence

\begin{tabular}{|c|c|c|c|c|}
\hline & Level of studies & Mean Rank & $x^{2}$ & p \\
\hline \multirow{5}{*}{$\begin{array}{l}\text { I have seriously considered dropping } \\
\text { out of my studies at HOU }\end{array}$} & High School Certificate & 40.13 & \multirow[t]{5}{*}{2.108} & \multirow[t]{5}{*}{.716} \\
\hline & $\begin{array}{l}\text { Bachelor degree of } \\
\text { Technological School }\end{array}$ & 48.13 & & \\
\hline & Bachelor degree & 40.54 & & \\
\hline & Master's degree & 47.00 & & \\
\hline & PhD & 23.50 & & \\
\hline \multirow[t]{5}{*}{ Self-esteem } & High School Certificate & 43.71 & \multirow[t]{5}{*}{1.907} & \multirow[t]{5}{*}{.753} \\
\hline & $\begin{array}{l}\text { Bachelor degree of } \\
\text { Technological School }\end{array}$ & 36.94 & & \\
\hline & Bachelor degree & 41.48 & & \\
\hline & Master's degree & 48.43 & & \\
\hline & $\mathrm{PhD}$ & 19.00 & & \\
\hline \multirow[t]{5}{*}{ Satisfaction with the course } & High School Certificate & 36.04 & \multirow[t]{5}{*}{5.276} & \multirow[t]{5}{*}{.260} \\
\hline & $\begin{array}{l}\text { Bachelor degree of } \\
\text { Technological School }\end{array}$ & 40.75 & & \\
\hline & Bachelor degree & 47.51 & & \\
\hline & Master's degree & 31.57 & & \\
\hline & $\mathrm{PhD}$ & 31.00 & & \\
\hline \multirow[t]{5}{*}{ Loneliness } & High School Certificate & 43.23 & \multirow[t]{5}{*}{1.867} & \multirow[t]{5}{*}{.760} \\
\hline & $\begin{array}{l}\text { Bachelor degree of } \\
\text { Technological School }\end{array}$ & 50.21 & & \\
\hline & Bachelor degree & 40.28 & & \\
\hline & Master's degree & 34.07 & & \\
\hline & PhD & 43.50 & & \\
\hline \multirow[t]{5}{*}{ Social presence } & High School Certificate & 37.65 & \multirow[t]{5}{*}{1.184} & \multirow[t]{5}{*}{.881} \\
\hline & $\begin{array}{l}\text { Bachelor degree of } \\
\text { Technological School }\end{array}$ & 44.93 & & \\
\hline & Bachelor degree & 42.91 & & \\
\hline & Master's degree & 44.07 & & \\
\hline & $\mathrm{PhD}$ & 31.50 & & \\
\hline
\end{tabular}

\section{Influence of marital status}

The independent variable of students' marital status was examined in relation to the dependent variables of self-esteem, loneliness, academic drop out, satisfaction with the course and students' perception of social presence. Marital status was measured dichotomically (Married / Single or Divorced). The Mann-Whitney $U$ test results (Table 7) showed that there are no statistically significant differences between marital status and the dependent variables mentioned above. 
Table 7: Influence of marital status on self-esteem, loneliness, academic drop out, satisfaction with the course and perceived social presence

\begin{tabular}{|c|c|c|c|c|}
\hline & Marital Status & $\begin{array}{c}\text { Mean } \\
\text { Rank }\end{array}$ & $\mathbf{U}$ & $\mathbf{p}$ \\
\hline \multirow{2}{*}{$\begin{array}{l}\text { I have seriously considered dropping out of my studies } \\
\text { at HOU }\end{array}$} & Married & 38.76 & \multirow[t]{2}{*}{537} & \multirow[t]{2}{*}{.132} \\
\hline & $\begin{array}{l}\text { Single/ } \\
\text { Divorced }\end{array}$ & 46.65 & & \\
\hline \multirow[t]{2}{*}{ Self-esteem } & Married & 41.53 & \multirow[t]{2}{*}{677} & \multirow[t]{2}{*}{.988} \\
\hline & Single/Divorced & 41.43 & & \\
\hline \multirow[t]{2}{*}{ Satisfaction with the course } & Married & 42.41 & \multirow[t]{2}{*}{625} & \multirow[t]{2}{*}{.580} \\
\hline & Single/Divorced & 39.17 & & \\
\hline \multirow[t]{2}{*}{ Loneliness } & Married & 39.67 & \multirow[t]{2}{*}{590} & \multirow[t]{2}{*}{.420} \\
\hline & Single/Divorced & 44.35 & & \\
\hline \multirow[t]{2}{*}{ Social presence } & Married & 40.91 & \multirow[t]{2}{*}{662} & \multirow[t]{2}{*}{.958} \\
\hline & Single/Divorced & 41.22 & & \\
\hline
\end{tabular}

\section{Discussion}

\section{Examining the relationship of self-esteem and loneliness with academic performance, academic drop out, satisfaction with the course and perceived social presence}

The correlational analyses clearly revealed a highly significant correlation between students' perceived self-esteem and academic drop out as well as between students' perceived self-esteem and their satisfaction with the course. More specifically, academic performance was found to be negatively correlated to measures of self-esteem, i.e. the higher the scores of self-esteem the lower the scores of academic drop out. As noted above, Pullmann and Allik (2008) concluded that self esteem is not necessarily a factor related to weak academic performance. Furthermore, Pellas (2014) noticed that students with modest academic performance compensated their deficiencies by considerably raising their self-esteem. On the other hand, as expected, self-esteem was found to be positively associated with students' satisfaction with the course: i.e. as the levels of self-esteem increase, the students' satisfaction with the course also increases. These results are consistent with other studies which have concluded that low levels of self-esteem is an important factor leading to dropping out of school (Kite, 1989; Bloom, 1997; Earle, 1987). In addition, selfesteem has been related to satisfaction with the course (Bhagat \& Chassie, 1978).

Although other studies have showed that academic performance is positively associated with selfesteem at all levels of education (Maqsud, 1983; Byrne, 1984; Marsch, 1990; Lane, Lane \& Kyprianou, 2004), this hypothesis was not confirmed by the present study. One possible explanation for this hypothesis not being confirmed, is the fact that in the current study the scale used for measuring self-esteem focused on a variety of aspects of self-esteem. If the self-esteem scale which was used had focused only in academic self-esteem, the results may have been different. This is an interesting point for further research.

Moreover the correlation analysis clearly showed that there are no statistically significant correlations between loneliness and the other the variables. Previous studies have shown that low school performance is tightly linked with loneliness (Valas, 1999; Hatzigeorgiadou, 2007; Cheng \& Furnham, 2002), while Pellas (2014) has noticed that the learning process is enhanced through collaborative learning tasks. The differences with the results of the present study could be explained by the assumption that loneliness may not play an important role in affecting academic performance or academic drop out in distance learning courses. Especially in relation to HOU, 
where students are not asked to hand in group written assignment for each of the course module they attend, It could be claimed that loneliness is not associated with academic performance since academic activities demand only individual effort. For instance, in the study of Asher et al. (1984) no relation was revealed between loneliness and school performance probably because students' reading ability was used for measuring school performance. Reading ability is a competence which is developed based on each student's individual effort and it is not related at all to group effort.

Finally, the correlation analysis clearly showed that the correlation between loneliness and selfesteem as well as the correlation between loneliness and social presence are statistically insignificant. The fact that loneliness was not found to be related with social presence could be attributed to the assumption that social presence in distance learning is not so much associated with the students' personal traits, but it is mostly related to the course design and the tutor's communication skills. Angelaki and Mavroidis (2013) examined HOU students' perception of social presence and found that the great majority of students often felt the need to contact their tutor and their peers in order to be academically and emotionally supported. Nevertheless, students were found to be rather hesitant to do so. The findings of their study also revealed that experiencing negative feelings such as loneliness and isolation motivated students to contact mostly with their fellow students. Consequently, it could be assumed that loneliness should be considered as a factor motivating students to take action - i.e. communicate with the tutor and peers - so that perceived social presence can increase.

\section{Examining demographic differences in relation to the correlation self-esteem and loneliness with academic performance, academic drop out, satisfaction with the course and perceived social presence}

Another purpose of the current study was to examine the demographic differences in relation to the variables under examination. More specifically gender, previous experience in distance learning, age, level of studies and family status were the demographic features used in this study. According to the findings of the study the levels of intention for academic drop out, self-esteem, loneliness and perceived social presence were not found to be related to demographic features examined here.

There has been a great research interest regarding gender differences in education. As for the relation between gender and self-esteem, female students were found to be less confident in all aspects of self-esteem compared to male ones according to Bolognini, Plancherel, Bettschart and Halfon (1996). However, Jacobs et al. (2002) and Pajares and Valiante (2001) after examining specific aspects of self-esteem in education, noticed that gender differences are related to specific aspects of students' self-esteem (e.g. self-esteem regarding the use of written discourse) and not to their general self-esteem score. The lack of gender differences in relation to self -esteem that was found in this study could be explained accordingly. Furthermore, a similar reasoning can be used to explain the lack of gender differences in relation to loneliness. For instance, Clinton and Anderson (1999) concluded that loneliness in men is linked with the lack of close friends while in women with the sense of control. The results of the present study were derived from the overall score of loneliness, which included several aspects of loneliness.

As far as social presence is concerned, the results revealed that there is no statistically significant difference between male and female students. Other studies having examined gender differences did so mainly in relation to social presence in online courses (Richardson \& Swan, 2003; Cyr et al., 2007). They all concluded that social presence in such courses is more significant to women rather than men. The fact that the results of the present study are not in agreement with the work of the above researchers could be attributed to the format of HOU courses, which are blended 
courses including face to face meetings. Face to face meetings may increase women's perception of social presence, bridging the gap with the men's perception of social presence which is noticed in courses offered online.

Finally no differences have been tracked concerning the rest of the demographic features examined in this study such as age, previous experience in distance learning, level of studies and family status. Though literature has not focused on such demographic features, they were examined in the current study as it had been assumed that these features may be influencing factors. Yet, no differences have been found.

\section{Conclusions and proposals for further research}

In conclusion self-esteem is a significant factor affecting students' academic success and especially their satisfaction with the distance learning course, reducing at the same time the students' intention to drop out. Therefore, it should be seriously taken into consideration by the distance learning provider when courses are designed as well as by the tutors during the courses. In addition, social presence in blended distance learning environments may not be associated with the students' personality traits such as self-esteem and loneliness, but more with the course design and the communication skills of the tutor. Consequently, taking into consideration the significance and the complexity of the tutor's role in such courses, one of the main priorities of the educational organization should to train the tutors so that they can develop the appropriate communication skills. Moreover, apart from academic support, tutor-student communication should involve issues of emotional and psychological support as well. Finally, assigning group written assignments to students would be rather helpful as it would probably reduce the feeling of loneliness and increase students' perception of social presence.

It should be stressed that there were certain limitations which may have influenced the findings of the present study. One limitation is that a restricted number of students were selected to participate in this study via purposive sampling. In this respect a larger sample - selected with random sampling methods - would enable further investigation of the relation between selfesteem, loneliness and social presence and parameters such as academic performance, academic drop out and satisfaction with the course in distance learning environments. The fact that the current study is a correlational study can be considered as another limitation of the study. Although the correlational method can establish a relationship between the correlated variables, it cannot establish a cause-effect relationship. Thus it would be useful to perform a longitudinal research in order to focus on the causes leading to the relationship between the examined parameters in a distance learning environment. It would also be significant to extend this research to courses offered totally online which emphasise on collaborative work. Additionally, it would be useful if more quantitative information regarding performance was available. Moreover, it would be of great interest to examine whether the results of the present study would be similar across different disciplines. Furthermore, the correlation of loneliness - or lack of it - with the rest of the variables would be an interesting point for further examination. Another point for future research could be what changes would be observed (on what can be considered as independent study with little student-student interaction) with an enforced social dynamic. Finally, further research could focus on specific aspects of self-esteem, as for example academic self-esteem, as well as on examining loneliness as a factor motivating students to take action that can increase social presence. 


\section{References}

1. Ali, A.; Ramay, M.I.; Shahzad, M. (2011). Key factors for determining student satisfaction in distance learning courses: a study of Allama IQBAL Open University. In Turkish Online Journal of Distance Education, 12(2), (pp. 114-127).

2. Angelaki, C.; Mavroidis, I. (2013). Communication and Social Presence: The Impact on Adult Learners' Emotions in Distance Learning. In European Journal of Open, Distance and eLearning, 16(1), (pp. 78-93). http://www.eurodl.org/materials/contrib/2013/Angelaki_Mavroidis.pdf

3. Arbaugh, J.B. (2000). Virtual classroom Characteristics and student satisfaction with internetbased MBA courses. In Journal of Management Education, 24, (pp.32-54).

4. Asher, S.R.; Hymel, S.; Renshaw, P.D. (1984). Loneliness in children. In Child Development, 55, (pp. 1456-1464).

5. Baumeister, R.F.; Campbell, J.D.; Krueger, J.I.; Vohs, K.D. (2003). Does high self-esteem cause better performance, interpersonal success, happiness, or healthier lifestyles? In Psychological Science in the Public Interest, 4, (pp. 1-44).

6. Bayne, S. (2014). What's the matter with 'technology-enhanced learning? In Learning, Media and Technology, DOI: 10.1080/17439884.2014.915851

7. Bayne, S.; Gallagher, M.S.; Lamb, J. (2014). Being 'at' university: the social topologies of distance Students. In Higher Education, 67, (pp. 569-583).

8. Bhagat, R.S.; Chassie, M.B. (1978). The role of self-esteem and locus of control in the differential prediction of performance, program satisfaction, and life satisfaction in an educational organization. In Journal of Vocational Behavior, 13, (pp. 317-326).

9. Bloom, S. L. (1997). Toward the Evolution of Sane Societies. New York: Routledge

10. Bolognini, M.; Plancherel, B.; Bettschart, W.; Halfon, O. (1996). Self-esteem and mental health in early adolescence: Development and gender differences. In Journal of Adolescence, 19, (pp. 233 -245).

11. Branden, N. (1969). The psychology of self esteem: A new concept of man's nature. Los Angeles: Nash Publishing.

12. Branden, N. (2001). The psychology of self esteem: A revolutionary approach to self understanding that launched a new era in modern psychology. San Francisco: Jossey-Bass.

13. Bryan, T. (1997). Assessing the personal and social status of students with learning disabilities. In Learning Disabilities Research \& Practice, 12(1), (pp. 63-76).

14. Byrne, B.M. (1984). The general/academic self concept nomological network: A review of construct validation research. In Review of Educational Research, 54, (pp. 427-456).

15. Cheng, H.; Furnham, G. (2002). Personality, peer relations, and self - confidence as predictors of happiness and loneliness. In Journal of Adolescence, 25, (pp. 327-339).

16. Clinton, M.; Anderson, L.R. (1999). Social and emotional loneliness: Gender differences and relationships with self-monitoring and perceived control. In Journal of Black Psychology, 25, (pp. 61-77).

17. Cyr, D.; Hassanein, K.; Head, M.; Ivanov, A. (2007). The role of social presence in establishing loyalty in e-Service environments. In Interacting with Computers, 19, (pp. 43-56).

18. Dillon, C.L.; Gunawardena, C.N.; Parker, R. (1992). Learner support: critical link in distance education. In Distance Education, 13(1). 
19. Earle, J. (1987). Female Dropouts: A New perspective. National Association of State Boards of Education, Alexandria. VA.

20. Finn, J.D. (1989). Withdrawing from school. In Review of Educational Research, 59, (pp. 117142).

21. Garrison, D.R.; Anderson, T.; Archer, W. (2000). Critical Inquiry in a text based environment: Computer conferencing in higher education. In The Internet \& Higher Education, 2(2/3), (pp. 87-105).

22. Garrison, D.R.; Arbaugh, J.B. (2007). Researching the community of inquiry framework: Review, issues \& future directions. In The Internet \& Higher Education, 10(3), (pp. 157-172).

23. Garrison, D.R. (2011). E-learning in the $21^{\text {st }}$ century: A framework for research and practice. (2 ${ }^{\text {nd }}$ ed.). London Routledge/Taylor and Francis.

24. Giossos, I.; Mavroidis, I.; Koutsouba, M. (2008). Research in distance education: review and perspectives. In Open Education, 4(1), (pp. 49-60) (in Greek with English abstract).

25. Griffiths, A.J.; Sharkey, J.D.; Furlong, M.J. (2009). Student Engagement and Positive School Adaptation. In R. Gilman, E.S. Huebner \& M.J. Furlong (eds.), Handbook of Positive Psychology in the Schools, (pp. 197-211). New York: Routledge.

26. Gunawardena, C.N.; Zittle, F. (1997). Social presence as a predictor of satisfaction within a computer mediated conferencing environment. In American Journal of Distance Education, 11(3), (pp. 8-25).

27. Gunawardena, C.N.; Nolla, A.C.; Wilson, P.L.; Lopez-Islas, J.R.; Ramirez-Angel, N.; Megchun-Alpizar, R.M. (2001). A Cross-Cultural Study of Group Process and Development in Online Conferences. In Distance Education, 22(1), (pp. 85-121).

28. Gunawardena, C.N.; McIsaac, M.S. (2004). Distance Education. In D.H. Jonassen (ed.), Handbook of research for educational communications \& technology ( ${ }^{\text {nd }}$ Edition), (pp. 355-395). London: Lawrence Erlbaum Associates.

29. Harmon-Jones, E.; Simon, L.; Greenberg, J.; Pyszcynski, T.; Solomon, S.; McGregor, H. (1997). Terror management and self-esteem: Evidence that self-esteem reduces mortality salience effects. In Journal of Personality and Social psychology, 72, (pp. 24-26).

30. Hatzigeorgiadou, S. (2007). Loneliness and Self-esteem in Primary School Children. Master's dissertation. Aristotle University: Thessaloniki (in Greek with English abstract).

31. Heatherton, T.F.; Polivy, J. (1991). Development and validation of a scale for measuring state self-esteem. In Journal of Personality and Social Psychology, 60, (pp. 895-910).

32. Hirsch, B.J.; DuBois, D.L. (1991). Self-esteem in early adolescence: The identification and prediction of contrasting longitudinal trajectories. In Journal of Youth and Adolescence, 20, (pp. $53-72)$.

33. Holmberg, B. (1995). Theory and practice of distance education. London: Routledge.

34. Hrastinski, S. (2009). A theory of online learning as online participation. In Computers and Education, 52, (pp. 78-82).

35. Jacobs, J.E.; Lanza, S.; Osgood, W.; Eccles, S.J.; Wigfield, A. (2002). Changes in Children's Self-Competence and Values: Gender and Domain Differences across Grades One through Twelve. In Child Development, 73(2), (pp. 509-527).

36. Keegan, D. (1986). The foundations of distance education. London Routledge.

37. Kite, H. (1989). How to Prevent Dropouts. Orlando Press, Florida. 
38. Kurtz, G.; Amichai-Hamburger, Y.; Kantor, J. (2009). Psychosocial well-being of Israeli students and attitudes toward open and distance learning. In The International Review of Research in Open and Distance Learning, 10(2).

39. Lane, J.; Lane, A.M.; Kyprianou, A. (2004). Self-efficacy, self-esteem, and their impact on academic performance. In Social Behavior and Personality, 32, (pp. 247-256).

40. Lionarakis, A. (2005). Open \& Distance Learning Universities in Europe. Two different educational considerations in search of identity. In Comparative \& International Review of the Hellenic Organisation of Comparative Education, Vol. 5. ISSN 1109-8678. (in Greek)

41. Maqsud, M. (1983). Relationships of locus of control to self-esteem, academic achievement, and prediction of performance among Nigerian secondary school pupils. In British Journal of Educational Psychology, 53, (pp. 215-221).

42. Marsch, H.W. (1990). Causal ordering of academic self concept and academic achievement: A multiwave, longitudinal panel analysis. In Journal of Educational Psychology, 82, (pp. 646-656.)

43. Maslow, A. (1971). The farther reaches of human nature. New York: The Viking Press.

44. Neff, K. (2011). Self-compassion, self-esteem and well-being. In Social and Personality Psychology Compass, 5(1), (pp. 1-12).

45. Neuman, W.L. (2003). Social Research Methods: Qualitative and quantitative methods approaches $\left(5^{\text {th }}\right.$ Ed.). Boston: Allyn and Bacon.

46. Pajares, F.; Valiante, G. (2001). Gender Differences in Writing Motivation and Achievement of Middle School Students: A Function of Gender Orientation? In Contemporary Educational Psychology, 26(3), (pp. 366-381).

47. Peixoto, F.; Almeida, L.S. (2010). Self-concept, self-esteem and academic achievement: Strategies for maintaining self-esteem in students experiencing academic failure. In European Journal of Psychology of Education, 25, (pp. 157-175).

48. Pellas, N. (2014). The influence of computer self-efficacy, metacognitive self-regulation and self-esteem on student engagement in online learning programmes: Evidence from the virtual world of Second Life. In Computers in Human Behavior, 35, (pp. 157-170).

49. Pullmann, H.; Allik, J. (2008). Relations of academic and general self-esteem to school achievement. Personality and Individual Differences, 45(6), (pp. 559-564).

50. Richardson, C.J.; Swan, K. (2003). Examining social presence in online courses in relation to students' perceived learning \& satisfaction. In Journal of Asynchronous Learning Networks, 7(1), (pp. 68-88).

51. Rosenberg, F.R.; Simmons, R.G. (1975). Sex differences in the self-concept in adolescence. In Sex roles, 1(2), (pp. 147-159).

52. Rourke, L.; Kanouka, H. (2009). Learning in Communities of Inquiry: A Review of the Litterature. In Journal of Distance Education, 23(1), (pp. 19-48).

53. Russel, D.W. (1996). The UCLA Loneliness Scale (Version 3): Reliability, validity and factorial structure. In Journal of Personality Assessment, 66, (pp. 20-40).

54. Shin, N. (2003). Transactional Presence as a Critical Predictor of Success in Distance Learning. In Distance Education, 24(1), (pp. 69-86).

55. Short, J.; Williams. E.; Christie, B. (1976). The social psychology of telecommunications. London: John Wiley and Sons. 
56. Skaalvik, E. M. (1983). Academic achievement, self-esteem and valuing of the school: Some sex differences. In British Journal of Educational Psychology, 53, (pp. 299-306).

57. So, H.J.; Brush, T.A. (2008). Student perceptions of collaborative learning, social presence \& satisfaction in a blended learning environment: Relationships \& critical factors. In Computers \&Education, 51, (pp. 318-336).

58. Stake, R. (1995). The art of case study research. Thousand Oaks, CA: Sage

59. Tajfel, H.; Turner, J.C. (1986). The social identity theory of inter-group behavior. In Worchel \& L.W. Austin (Eds.), Psychology of inter-group relations. Chicago: Nelson -Hall.

60. Tinto, V. (1993). Leaving college: rethinking the causes and cures of student attrition. Chicago: University of Chicago Press.

61. Tu, C.-H. (2002). The measurement of social presence in an online learning environment. In International Journal on E-Learning, April-June, (pp. 34-45).

62. Valås, H. (1999). Students with learning disabilities and low-achieving students: Peer acceptance, loneliness, self-esteem and depression. In Social Psychology of Education, 3, (pp. 173 192).

63. von Prummer, C. (1990) Study motivation of distance students: a report on some results from a survey done at the FernUniversitat in 1897/88. In Research in Distance Education, 2(2), (pp. 2-6).

64. Weinner, B. (2000). Intrapersonal and interpersonal theories of motivation from an attributional perspective. In Educational Psychology Review, 12, (pp. 1-14).

65. Weiss, R.S. (1973). Loneliness. The experience of emotional and social isolation. Cambridge, MA: The MIT Press.

66. Whiteman, J.A.M. (2002). Interpersonal Communication in Computer Mediated Learning. Opinion paper (ED 465 997).

67. Workman, J.J.; Stenard, R.A. (1996). Student support services for distance learners, In DEOSNEWS, 6(3). Retrieved November 3, 2014 from the Distance Education Online Symposium Website: http://learningdesign.psu.edu/deos/deosnews6_3.pdf 